\title{
The Meaningful Place: Transforming Taman Sari Banda Aceh as City Park
}

\author{
Rahmalia ${ }^{1} \Varangle$ \\ Nurul Hikmah ${ }^{2}$ \\ 'School of Journalism and Communication, Huazhong University of Science and Technology (HUST), Wuhan, \\ 430074, P. R. China \\ Email:rahmalia@hust.edu.cn \\ ${ }^{2}$ School of Education Studies, Universiti Sains Malaysia (USM), Gelugor 11800 , Penang, Malaysia
}

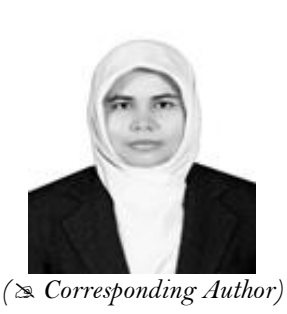

\begin{abstract}
City Park is a public space which should be utilized optimally by the community. One of the city parks intersecting with the center of facilities and infrastructure of Banda Aceh city is Taman Sari. The condition of the urban park in Banda Aceh city is not comfortable enough. Therefore, people tend not to use public space optimally, in this case, as a place for interacting and holding the certain events. This research was intended to conduct a systematic observation on the utilization of Taman Sari (the city park) to maximize its function as public area and manage the efforts for the improvement of the area related to transformation of recreational area as the local playground into more meaningful, purposeful and useful site in term of social, economic, and environment sectors. The data obtained through field surveys, interviews and the study of literature as well as providing documentation about the activities of the community by analyzing the qualitative descriptive methods. The result showed that the city park which was also as the representative public open area in Banda Aceh did not provide public facilities sufficiently. Therefore, the existence of the city park would not only act as a playground but it could be more functional and beneficial in accordance with social and recreational activities, community creative art and entertainment, entrepreneurial activities as well as environmental conservation. The Availability of public facilities would provide more attracting values to invite public to utilize the area as the center for many activities.
\end{abstract}

Keywords: The meaningful place, City Park, Taman Sari, Transforming, Banda Aceh.

Citation | Rahmalia; Nurul Hikmah (2018). The Meaningful Place: Transforming Taman Sari Banda Aceh as City Park. Asian Journal of Social Sciences and Management Studies, 5(4): 147-152.

History:

Received: 29 June 2018

Revised: 2 August 2018

Accepted: 10 September 2018

Published: 19 October 2018

Licensed: This work is licensed under a Creative Commons

Attribution 3.0 License (c) E E

Publisher:Asian Online Journal Publishing Group
Contribution/Acknowledgement: Both authors contributed to the conception and design of the study.

Funding: This study received no specific financial support.

Competing Interests: The authors declare that they have no conflict of interests.

Transparency: The authors confirm that the manuscript is an honest, accurate, and transparent account of the study was reported; that no vital features of the study have been omitted; and that any discrepancies from the study as planned have been explained.

Ethical: This study follows all ethical practices during writing.

\section{Contents}

1. Introduction

2. The Methods

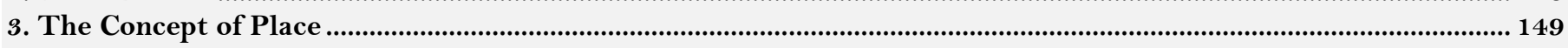

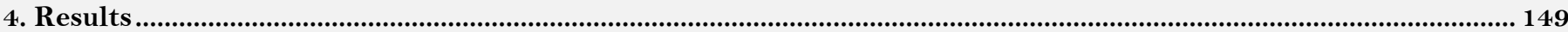

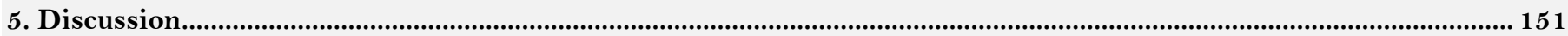

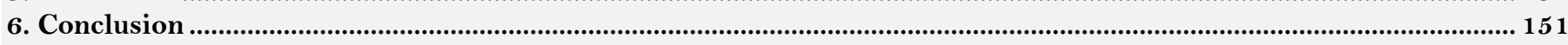

References . . 


\section{Introduction}

City Park is a public space which should be utilized optimally by the community. One of the city parks intersecting with the center of facilities and infrastructure of Banda Aceh city is Taman Sari.

One of the public parks (Rahmad and Yulianti, 2017) and also the historical places (AR, 2012) in Banda Aceh, Taman Sari is strategically located between some other important places. Masjid Raya Baiturrahman, one of the grand mosques in Banda Aceh is located 200 meters (Yudistira, 2015) on its southern side, while its Eastern side is located straightly in front of the Mayor of Banda Aceh Office and other government offices.

After tsunami disaster (AR, 2012) hit Aceh in 2004, Taman Sari was renovated. Some old facilities are replaced with the new ones due to lost affected by the tsunami. Some new facilities are, park benches, kids games facilities, hot spot internet connection area, parking place, pedestrian, a place providing the water for public, gathering place, park lighting, walking path, and food courts. Besides, the government also provides the toilet and praying place to make the people feel comfortable.

Taman Sari is an open area used as the public place to hold some events held by the government or nongovernment in Banda Aceh, namely, Banda Aceh Expo, Product and Service for National travel and handcarving event, Exhibition, Culture and Art festivals.

The condition of this city park has fulfilled the standard as a city park (Yudistira, 2015) but it's still lack of green and public area (Sari, 2014; Rahmad and Yulianti, 2017).It is also lack of facilities needed to hold the big events, as well (Rahmad and Yulianti, 2017).

This paper is talk about the history, the meaningful place, function and the transformation of Taman Sari as well. Exploring how to use a place to be more important and meaningful, not only as a recreation place and waiting for place, but also to be a place where the social interaction can be done and also as people's activities area.

\subsection{Historical Background}

Aceh (Crow, 2000; Thaib, 2000; AR, 2012) is a province located on the tip of Northern Sumatera island (Thaib, 2000; McGregor, 2010; Ichwan, 2011) and also the last province in Western Indonesia(Jemadu, 2004). Aceh is a province with special autonomy (Sulistiyanto, 2001; Ichwan, 2011; Vignato, 2012) given by Indonesian Government (Sulistiyanto, 2001) with Banda Aceh as the capital city. Banda Aceh is a city which surrounded by the beaches from the Western Indonesia coastal area. There are so many historical sites left by the previous Kingdom (Oga and Husaini, 2017) in this place. There are so many struggling histories to fight the colonial (Crow, 2000; Sulistiyanto, 2001; Jemadu, 2004; Aspinall, 2007; Grayman et al., 2009) as well as releasing from the long conflict (Sulistiyanto, 2001; McCarthy, 2007; McCawley, 2014). The story about the cooperation with other kingdoms all over the world(Jemadu, 2004)the capital of the world trade (Aspinall, 2007) the story of sea traffic (Sufi, 1996) and a crowded transportation place by that time (Jemadu, 2004) in Indian Ocean, until the story of being a destroying city by tsunami disaster.

A park which was described in the old manuscripts(Harun, 2004)the place where the Sultan's family was playing (Ichwan, 2011) is Taman Sari located in the middle of the city and one of the sites (Yudistira, 2015) which was often visited by the people.

At the first time, this park is only a playground for the Sultan's family (Ichwan, 2011) which was full of plants and flowers, and left empty until Aceh was free from Dutch colonial expansion (Kreike, 2012). There was no building there at that time. In 1945 the freedom tower was built there for remembering that Banda Aceh was a capital area for Indonesia.

Being a strategic place, with a long landscape, which is close to any other tourism places like Tsunami Museum, Peutjoet Kerkhof (a mass grave which one of Dutch General, Kohler, and many other soldiers were buried), Blang Padang Field, Aceh's Museum (Aceh's house), Putroe Phang park and also Gunongan Park, made Taman Sari become a real favorite place for family recreation, for discussion, for gathering, and also for the kids playground, as well as the relaxing place for waiting another member of family doing shopping in Aceh's Market (about 300 meters from the park) or getting meeting with someone in the offices placed across this park.

As it was told about the history in the past, this park is a proof about the development of Banda Aceh City from the Kingdom era to the modern government era.

\subsection{Objectives of the Study}

This research was intended to conduct a systematic observation on the utilization of Taman Sari (the city park) to maximize its function as public area and manage the efforts for the improvement of the area related to transformation of recreational area as the local playground into more meaningful "Place", purposeful and useful site in term of social, economic, and environment sectors.

This study focuses on the transformation of Taman Sari as the city park after the end of the tsunami disaster in Aceh. The big disaster had created the Acehnese history, as time went on, served as its main rationale for continued the new life in.

\section{The Methods}

\subsection{Methods Design}

The data obtained through field surveys, interviews and the study of literature as well as providing documentation about the activities of the community by analyzing with the qualitative (Creswell et al., 2003; Yin, 2009) descriptive methods.

Taman Sari the city park of Banda Aceh was chosen as a study site for this research because it is one of the most strategic and accessible place (Lukermann, 1964; Relph, 1976; Cresswell, 2008) located in the middle of city density. 


\subsection{Overview of the Research Site}

The research was conducted in Taman Sari, the city park located in the one of most congested areas in the middle of Banda Aceh city, Aceh Province, associated with buildings, the area of stores, offices, Masjid (Grand Mosque), Tsunami Museum, and other cultural sites.

The position of this city park is very potent because it is located only 200 meters on the southern side of Baiturrahman Mosque. The eastern side of the park is directly opposite the Mayor's Office of Banda Aceh and other office buildings.

\section{The Concept of Place}

Place is in more than just a location and can be described as a location (Lukermann, 1964; Relph, 1976) created by human experiences. In fact 'place' that is filled with meanings and objectives by human experiences (includes art, monument, architecture) in this particular space. Places are centers where people can satisfy, there biological needs such as food, water etc (Tuan, 1977).

The idea that place, to be a place, necessarily has meaning. Although there are glimmers of this idea throughout the history of geography, it grew in popularity in the modern discipline with the rise of humanistic geography (Tuan, 1977). And a host of others approached place as a subjectively sensed and experienced phenomenon (Relph, 1976).

In each of these cases, the place is where the land is so very different from its surroundings that it deserves a name all its own. The museum is an attempt to produce a 'place of memory' will not be forgotten (Cresswell, 2008). The gardens are the result of the efforts of others to carve out a place from a little piece of the human for their community to enjoy nature. We give them special names and call them "places". A place can be labeled in several different ways. All of these are examples of the ongoing and diverse creation of places - sites of history and identity in the city.

\section{Results}

Each city has its own history which becomes the starting point of the city's development. To this day, Taman Sari, which in the past was famous as the playground for the Sultan's family, is still continuing to transform and is trying to restore its landscape.

Visitors can experience the place, and enjoy the historical royal family atmosphere in this modern era. This place also serves a hotspot area where people can freely access the internet. There are also children's playground facilities, gathering place, and recreational facilities. Visitors can meet with friends or relatives. They also can do discussion, do exercise, or merely spend their leisure time. They can find it all in this green open space with modern nuances.

\subsection{Taman Sari as the City Park}

For a long time, this park has been an outdoor recreational place for the people of Banda Aceh especially, or for Acehnese in general. Especially, this park had been a meeting point for some people, but so many changes have taken place after the Tsunami disaster hit Aceh on December 26, 2004 (Ratrin Hestyanti, 2006; Jauhola, 2010). After being rehabilitated and reconstructed, Taman Sari has changed in many aspects.

Before that, there were only minor changes happened in Taman Sari. That is as the researcher witnesses, since the researcher has been visiting the city park with family and friends for as long as the researcher can remember, and so the researcher has seen how it has changed for the last twenty years. However, basically, Taman Sari has remained very much the same.

Even when the researcher is away from her hometown, the researcher can still remember the family atmosphere compelled by this place. This park is not very wide, it is only about 2370.00 meters square (Department of Environment Cleanliness and Beauty City of Banda Aceh (DLHK3), 2013) but this is supposed to be one of the reasons which ease people to interact with each other. Moreover, people can enjoy the city view, and it is also close to the Baiturrahman Grand Mosque as well as to the market and the government offices. It makes the Taman Sari as a city park has always been a destination to visit.

\subsection{Transforming Taman Sari to the Meaningful Place}

The result showed that Taman Sari which was also as a representative public open area in Banda Aceh did not provide public facilities sufficiently (Sari, 2014). Whereas, the availability of public facilities is crucial to encourage people to visit a place. Therefore, the existence of the city park would not only act as a playground but it could be more functional and beneficial in accordance with social and recreational activities, community creative art and entertainment, entrepreneurial activities as well as environmental conservation.

As one of the city icons, Taman Sari has begun to transform, the atmosphere is comfortable as a playground, a place to relaxing, a stopover or a place to waiting, a place to a gathering, witness various cultural exhibitions and local art performances. In addition to the existing facilities (leafy trees, park benches, adequate waste, parking) especially if coupled with more play rides for children, becoming a more purposeful place rather than just a recreational place (Tate and Eaton, 2015) for the community.

The availability of public facilities would provide more attracting values to invite public to utilize the area as the centre for many activities. Briefly, this public area would serve the community in conducting certain event or activities. There are a lot of memories for the community who often make Taman Sari as a meeting point, or only as a gathering place, but still can see the activity of urban people on working days. 


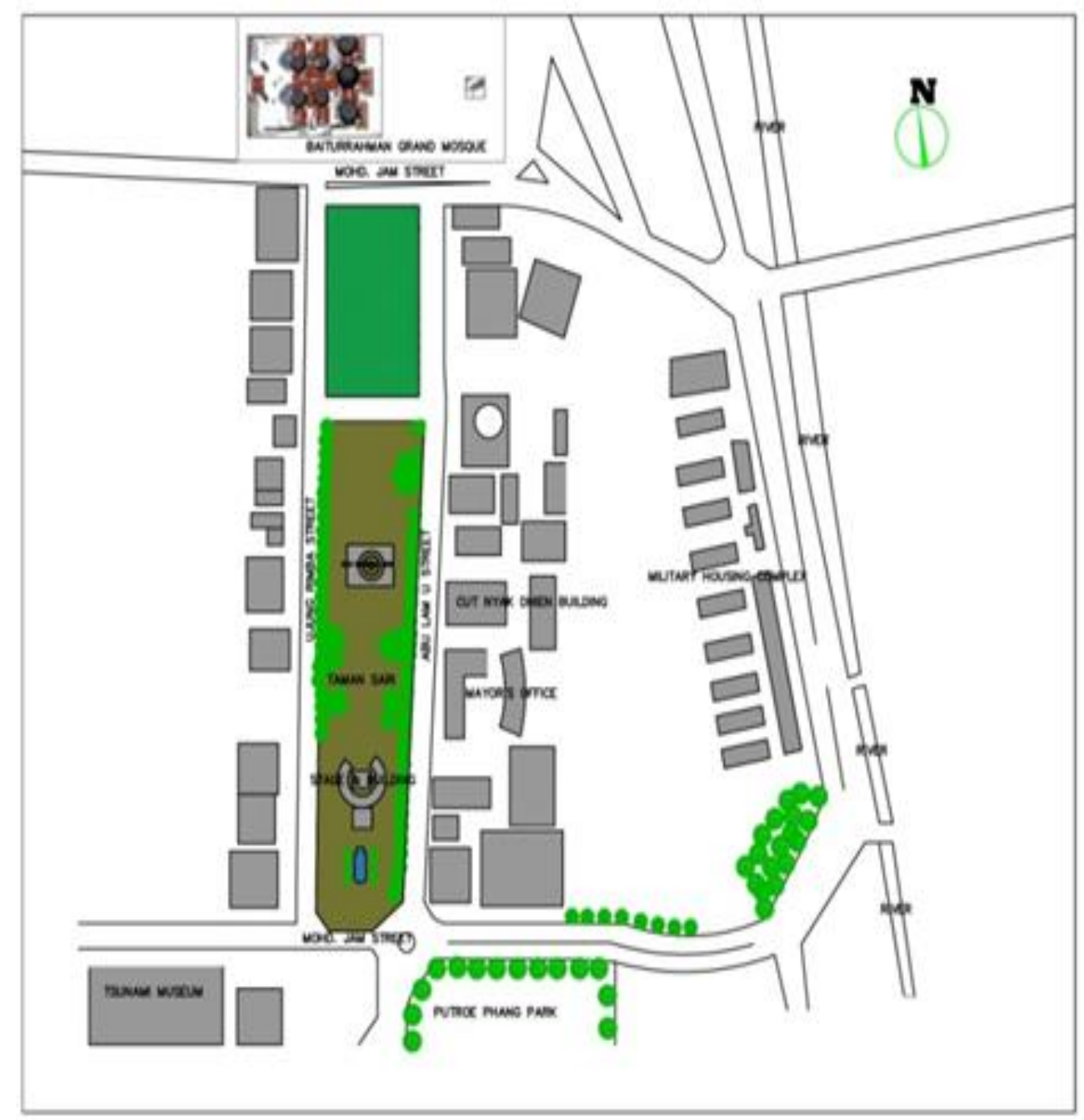

Source: Authors, 2017

Figure-1. Location of Taman Sari the City Park

The availability of facilities and infrastructure in the city centre raises the attraction for the community to do activities. The city park (Tate and Eaton, 2015) is a place where people engage in social interaction and social activities. When you walk in Taman Sari or gather in the playground, you are experiencing the outcome of that meaning.

Nevertheless, the change of function has not been followed by improvement of its quality as a city park (Rahmad and Yulianti, 2017). In its efforts to increase the intensity of utilization, Taman Sari is already acting as a city park, functioning socially, ecologically and aesthetically (Yudistira, 2015) but it is still not maximal, its facilities as a green open space and public space is still lacking (Sari, 2014). As facilities to support major events are not yet supported, it becomes less interesting to conduct events. The event organizers have to make a stand/use a nonpermanent building, demolish it once the event is done. There is no permanent building that can facilitate the event held there.

To improve the quality of the city park, actions must be done through the arrangement, good facilities, improvement of utilization, and socialization (publication). This is to increase visitors and utilization of the city park as a public space in Banda Aceh. The addition of multifunction shelter in the park can be useful as a protective area of the sun or rain, and can also be used as a place of exhibition, and art performances (piasan senı). It is necessary to take these actions for the creation of Taman Sari as a representative city park for a part of the public space of Banda Aceh.

\subsection{The Meaningful Place}

A good city park provides security and comfort for the community in performing activities. It should also link all creativity of children with the performances of various arts and performances of natural products or local products, and the interest of the urban area.

Good facilities will improve the image of Taman Sari as a city park, so it worth a visit. Furthermore, the urgent issue is how to improve the image of Banda Aceh through landmark (Taman Sari).

Since 2004, Taman Sari has transformed to become more beneficial to the community. The researcher does not consider Taman Sari as an ordinary city park, as time goes by, the researcher sees Taman Sari as a meaningful place. Taman Sari has become an icon or a landmark (Lynch, 1960) of Banda Aceh, which is being developed after earthquake and tsunami.

Banda Aceh has been recognized nationally as the capital of the province. The city represents Acehnese culture, its cultural diversity, and religious diversity. It is a special place that represents Aceh today. Most people interpret meaning about a community by cultural values they see in a community.

It is to encourage the community to consider using the place for social interactions and other activities (or doing other programs). If a place can be defined as relational, historical and related to identity, then space which cannot be defined as relational, historical, or concerned with identity will be a non-place (Auge, 1996). 
Some cities have been developing their own sustainability indicators, to try and measure the quality of life issues in a meaningful way.

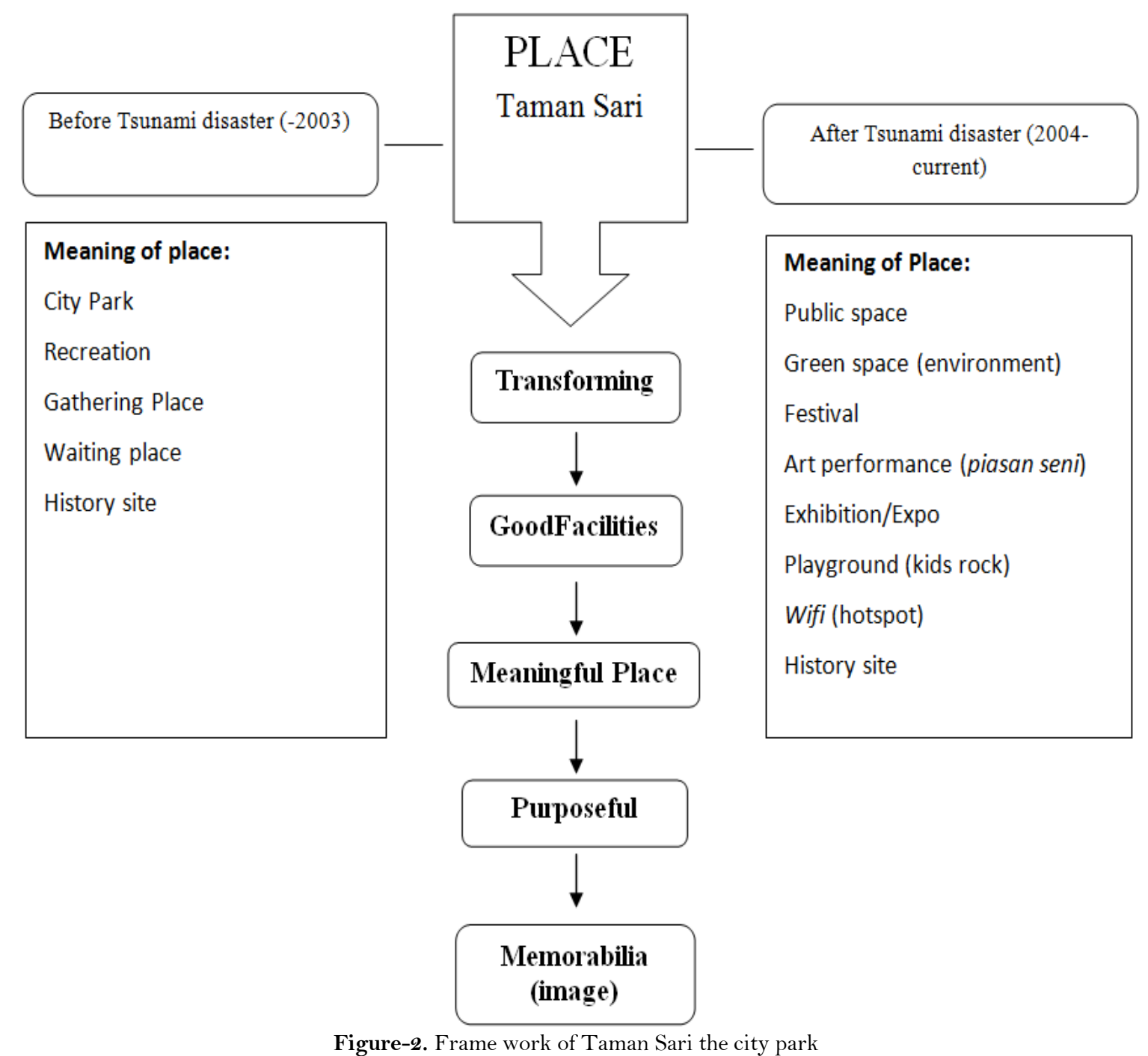

Source Authors, 2017

Figure-2. Frame work of Taman Sari the city park

\section{Discussion}

It analyzed some of the ways to improve the image of the city park so it will be more well-known, interesting to visit, and leaving a great impression. Thus, with good facilities and comfortable atmosphere, it will make visitors and the public remember Taman Sari as a meaningful place to visit. It will also become a valuable tourist destination worth to be publicized, and eventually will be an important landmark of Banda Aceh city.

This research provides interesting information to all parties, city-planners, visitors, researcher, government, and the community, in order to create Taman Sari as a purposeful and meaningful place as the city park. Consequently, it will improve good image to outsiders about the role and importance of public green space for the citizens' well being and quality of life.

People's relationships and connections with their places have shown how a place can act as a gift. In the past and in the future, ancestors and descendants are an inalienable presence to particular places. These may be nurtured, in the way we help to conserve the park and the homeland.

\section{Conclusion}

With the socialization of Taman Sari as a city park owned by the public, it is supposed to be an open space that is free to be used for any public activity. Provided that, the cleanliness and beauty of the city park should always be maintained. Consequently, the public knows that Taman Sari does not belong to certain parties, and is intended for the citizens instead. Although, of course, the government is responsible for managing the maintenance and supporting facilities in the park.

By this research, we can find out how the city park reaches the feasibility standard by increasing the comfort and facilities of the Taman Sari as a city park and green open space in Banda Aceh and able to make it as a landmark of Kota Banda Aceh.

As a suggestion, to deepen the understanding, a broader perspective and other methods may be implemented in order to further study the field, an interdisciplinary approach should be conducted to study the city park as a meaningful place.

\section{References}

AR, N., 2012. The Manuscript Collection of the Aceh Museum. Indonesia and the Malay World, 40(116): 94-110.Available at: https://doi.org/10.1080/13639811.2011.649001.

Aspinall, E., 2007. From Islamism to nationalism in Aceh, Indonesia. Nations and Nationalism, 13(2): 245-263.Available at: https://doi.org/10.1111/j.1469-8129.2007.00277.x.

Auge, M., 1996. Non-places: Introduction to an anthropology of supermodernity. Capital \& Class, 60: 144. Available from https://doi.org/10.1177/030981689606000111.

Cresswell, T., 2008. Place: Encountering geography as philosophy. Geography, 93(3): 132-139. 
Creswell, J.W., V.L. Plano Clark, M.L. Gutmann and W.E. Hanson, 2003. Advanced mixed methods research designs. Handbook of Mixed Methods in Social and Behavioral Research. 2nd Edn., California: SAGE Publication, 209: 240.

Crow, K.D., 2000. Aceh-the'special territory'in North Sumatra: A self-fulfilling promise? Journal of Muslim Minority Affairs, 20(1): 91104.Available at: https://doi.org/10.1080/13602000050008915.

Department of Environment Cleanliness and Beauty City of Banda Aceh (DLHK3), 2013. Parks and other green open space (green open space). Available from http://dlhk3.bandaacehkota.go.id/taman-dan-rth-lainnya/ [Accessed January 2017].

Grayman, J.H., M.-J.D. Good and B.J. Good, 2009. Conflict nightmares and trauma in Aceh. Culture, Medicine, and Psychiatry, 33(2): 290312.Available at: https://doi.org/10.1007/s11013-009-9132-8.

Harun, J., 2004. Bustan Al-Salatin,'the garden of kings': A universal history and ADAB work from seventeenth-century ACEH. Indonesia and the Malay World, 32(92): 21-52.Available at: https://doi.org/10.1080/1363981042000263444.

Ichwan, M.N., 2011. Official Ulema and the politics of re-Islamization: The Majelis Permusyawaratan Ulama, Sharī'atization and contested authority in post-new order Aceh. Journal of Islamic Studies, 22(2): 183-214.Available at: https://doi.org/10.1093/jis/etro26.

Jauhola, M., 2010. "When house becomes home"-Reading normativity in gender equality advocacy in Post-Tsunami Aceh, Indonesia. Gender, Technology and Development, 14(2): 173-195.Available at: https://doi.org/10.1177/097185241001400203.

Jemadu, A., 2004. Searching for a more participatory approach to resolving the Aceh conflict. Inter-Asia Cultural Studies, 5(3): 443449.Available at: https://doi.org/10.1080/1464937042000288723.

Kreike, E., 2012. Genocide in the Kampongs? Dutch nineteenth century colonial warfare in Aceh, Sumatra. Journal of Genocide Research, 14(3-4): 297-315.Available at: https://doi.org/10.1080/14623528.2012.719367.

Lukermann, F., 1964. Geography as a formal intellectual discipline and the way in which it contributes to human knowledge. Canadian Geographer, 8(4): 167-172.Available at: https://doi.org/10.1111/j.1541-0064.1964.tbo0605.x.

Lynch, K., 1960. The image of the city. The Journal of Aesthetics and Art Criticism, 21(1): 91.Available at: https://doi.org/ 10.2307/427643.

McCarthy, J.F., 2007. The demonstration effect: Natural resources, ethnonationalism and the Aceh conflict. Singapore Journal of Tropical Geography, 28(3): 314-333.Available at: https://doi.org/10.1111/j.1467-9493.2007.00304.x.

McCawley, P., 2014. Book review: Separatist conflict in indonesia: The long-distance politics of the acehnese diaspora missbachantje, separatist conflict in indonesia: The long-distance politics of the acehnese diaspora. London and New York: Routledge South East Asia Research.

McGregor, A., 2010. Geographies of religion and development: Rebuilding sacred spaces in Aceh, Indonesia, after the tsunami. Environment and Planning A, 42(3): 729-746.Available at: https://doi.org/10.1068/a4273.

Oga, U.D. and T.A. Husaini, 2017. The role of Aceh cultural heritage conservation center (BPCB) in preservation of historic sites in Banda Aceh City Year 1990-2015. Scientific Journal of Students of History Education Department, Banda Aceh, 2(1).

Rahmad and C.S. Yulianti, 2017. The role of Taman Sari as a Formator of Banda Aceh City Aesthetics, 2(3): 130-133.

Ratrin Hestyanti, Y., 2006. Children survivors of the 2004 Tsunami in Aceh, Indonesia. Annals of the New York Academy of Sciences, 1094(1): 303-307.Available at: https://doi.org/10.1196/annals.1376.039.

Relph, E.C., 1976. Place and placelessness. London: Pion.

Sari, L.H.A.S.P., 2014. The effectiveness of the Taman Sari as a public open space in the city of Banda Aceh. Journal of Architecture Unsyiah, 1: 1-10.

Sufi, R., 1996. History of Banda Aceh Municipality. Directorate General of Culture, Banda Aceh.

Sulistiyanto, P., 2001. Whither Aceh?. Third World Quarterly, 22(3): 437-452. Available from https://doi.org/10.1080/0143659012006169.
and M. Eaton, 2015. Great city parks. 2nd Edn., Great City Parks. Routledge. pp: 106.

Tate, A. and M. Eaton, 2015. Great city parks. 2nd Edn., Great City Parks. Routledge. pp: 106.
Thaib, L., 2000. Aceh's case: Possible solution to a festering conflict. Journal of Muslim Minority Affairs, 20(1): 105-110.Available at: https://doi.org/10.1080/13602000050008924.

Tuan, Y.-F., 1977. Space and place: The perspective of experience. Contemporary Sociology. Minneapolis: Minnesota Press. pp: 4.

Vignato, S., 2012. Men come in, men go out': Single Muslim women in Malaysia and Aceh. Social Identities, 18(2): 239-257.Available at: https://doi.org/10.1080/13504630.2012.652847.

Yin, R.K., 2009. Case study research: Design and methods. Essential guide to qualitative methods in organizational research. Available from https://doi.org/10.1097/FCH.obo13e31822dda9e.

Yudistira, H., 2015. Evaluation of the City Park utilization case study: Taman Sari Kota Banda Aceh. ETD Unsyiah., Banda Aceh. (Thesis). 